\title{
Muscarinic acetylcholine response in pyramidal neurones of rat cerebral cortex
}

\author{
M. Nishikawa, M. Munakata \& 'N. Akaike \\ Department of Bio-Plasticity, Kyushu University Faculty of Medicine, Fukuoka 812, Japan
}

1 The effects of acetylcholine ( $\mathrm{ACh})$ on pyramidal neurones acutely dissociated from the rat cerebral cortex were studied in the whole-cell mode, by use of the nystatin-perforated patch recording configuration.

2 ACh induced a net inward current $\left(I_{\mathrm{ACh}}\right)$ accompanied by a membrane conductance decrease at a holding potential $\left(\mathrm{V}_{\mathrm{H}}\right)$ of $-40 \mathrm{mV}$. $I_{\mathrm{ACh}}$ increased in a concentration-dependent manner with a halfmaximum concentration $\left(\mathrm{EC}_{50}\right)$ of $8.7 \times 10^{-7} \mathrm{M}$.

$3 I_{\mathrm{ACh}}$ mainly resulted from the suppression of the voltage- and time-dependent $\mathrm{K}^{+}$current (Mcurrent).

4 Muscarine and muscarinic agonists such as McN-A-343, oxotremorine and oxotremorine-M mimicked the ACh response. The potency was in the order of oxotremorine-M $>\mathrm{McN}-\mathrm{A}$ $343 \geqslant$ muscarine $>$ oxotremorine.

5 Pirenzepine shifted the concentration-response curve for ACh to the right and the corresponding Schild plot yielded a $\mathrm{pA}_{2}$ value of 7.81. Other muscarinic antagonists also reversibly blocked $I_{\mathrm{ACh}}$ in a concentration-dependent manner. The inhibitory potency was in the order of atropine $>4$-DAMP $>$ pirenzepine > AF-DX-116.

$6 I_{\mathrm{ACh}}$ could be induced normally even after pre-incubation of dissociated neurones in external solution with $200 \mathrm{ng} \mathrm{ml}^{-1}$ pertussis toxin (PTX) for $8 \mathrm{~h}$, whereas the inhibitory effect of ACh on high-voltageactivated $\mathrm{Ca}^{2+}$ channels was completely abolished by the PTX treatment.

Keywords: Rat cortical pyramidal neurone; muscarinic acetylcholine receptor; M-current

\section{Introduction}

The cholinergic innervation to the cerebral cortex has intrigued investigators for many years because of its possible roles in higher brain functions such as arousal, memory and learning (Squire \& Davis, 1981). Interest in the cortical cholinergic system has been stimulated further by the fact that there are deficits of this system in patients with Alzheimer's disease (Coyle et al., 1983). One major step toward understanding this system was the study of the muscarinic acetylcholine receptors in the central nervous system (McKinney \& Richelson, 1984). The activation of muscarinic receptors has been shown to evoke a wide variety of responses, suggesting that multiple subtypes might exist. Molecular biological studies have confirmed the existence of at least five distinct subtypes $(\mathrm{ml}-\mathrm{m} 5)$ of muscarinic receptor genes (Bonner, 1989). The $\mathrm{ml}-\mathrm{m} 4$ genes correspond most closely to the pharmacologically defined $\mathbf{M}_{1}-\mathbf{M}_{4}$ subtypes, respectively (Hulme et al., 1990; Lazareno et al., 1990).

Many biochemical and electrophysiological studies have addressed the $\mathrm{ACh}$ response in the mammalian cortex. In the rat cortex, the activation of muscarinic receptors stimulates phosphoinositide hydrolysis (Downes, 1982) and evokes a synaptic inhibition and a slow excitation (Krnjevic et al., 1971; Krnjevic, 1974). In the guinea-pig cortex, the muscarinic receptor with high affinity for pirenzepine depolarizes the pyramidal neurones, while that with low affinity for pirenzepine is involved in the activation of inhibitory interneurones (McCormick \& Prince, 1985). The AChinduced depolarization of pyramidal neurones is mainly due to a decrease in a voltage-dependent $\mathrm{K}^{+}$current known as the M-current $\left(I_{\mathrm{M}}\right.$; Brown \& Adams, 1980). However, the muscarinic receptor subtypes and the pharmacological properties involved in these responses have not been fully elucidated in this brain area.

In the present study, therefore, we investigated quan-

1 Author for correspondence. titatively the ACh-induced response and its pharmacological properties in mammalian cortical neurones under voltageclamp conditions. For this purpose we used pyramidal neurones acutely dissociated from the rat cerebral cortex. The nystatin perforated patch recording configuration was used to maintain, intact, the intracellular second messenger systems.

\section{Methods}

\section{Preparation}

Single pyramidal neurones of the cerebral cortex were acutely dissociated as reported previously (Ito et al., 1991). Briefly, 1to 2-week-old Wistar rats were decapitated under deep ether anaesthesia. The area between 2 and $4 \mathrm{~mm}$ from the anterior tip of the frontal lobe was cut into coronal slices $(350 \mu \mathrm{m}$ thick) with a microslicer (D.S.K., Model DTK-1000), and pre-incubated in incubation solution saturated with $95 \%$ $\mathrm{O}_{2}: 5 \% \mathrm{CO}_{2}$ for $40 \mathrm{~min}$ at room temperature $\left(22-25^{\circ} \mathrm{C}\right)$. Thereafter, the slices were treated with enzymes. The enzyme treatments were made first in an oxygenated standard external solution with $0.015 \%$ pronase for $15 \mathrm{~min}$ at $31^{\circ} \mathrm{C}$ and successively in $0.015 \%$ thermolysin under the same conditions. The slice preparations were then rinsed with $\mathrm{Ca}^{2+}$-free EGTA external solution and incubated for another $15 \mathrm{~min}$ in standard solution. The dorsomedial portion of the cortex was micro-punched out and dissociated mechanically with fine fire-polished glass Pasteur pipettes in a small plastic culture dish (Falcon) filled with the standard solution. Dissociated neurones adhered to the bottom of the dish within $30 \mathrm{~min}$, allowing electrophysiological studies to be conducted. The neurones having the original morphological features of pyramidal neurones such as the pyramidal somatic shape and the prominent apical dendritic process were used. 


\section{Electrical measurement}

Electrical recordings were performed by use of the nystatin perforated patch recording with some modifications (Wakamori et al., 1993). Patch pipettes were fabricated from glass capillaries (Narishige, $1.5 \mathrm{~mm}$ outer diameter) on a two-state puller (Narishige, PB-7). The resistance between the patchpipette filled with the internal soluton and the reference electrode was 4 to $8 \mathrm{M} \Omega$. After formation of the stable perforated patch, the series resistance ranged from 16 to $20 \mathrm{M} \Omega$. Ionic currents and voltages were measured with a patch-clamp amplifier (List Electronic, EPC-7). Signals were filtered with a low-pass filter (NF Electronic Instruments, FV-665) at a cut off frequency of $1 \mathrm{kHz}$ and were monitored simultaneously on a storage oscilloscope (Iwatsu, MS-5100A) and a pen-recorder (San-ei, RECTI HORIZ 8K). Records were stored on a video cassette recording system (Mitsubishi, HV-F93) via a pulse coded modulation processor (SONY, PCM 501) for subsequent analysis using the pCLAMP system (Axon Instruments). All the experiments were performed at room temperature $\left(22-25^{\circ} \mathrm{C}\right)$.

\section{Statistical analysis}

The data are presented as the mean \pm standard error of the mean (s.e.mean) in the text, and the s.e.mean is indicated by a vertical bar in figures.

The continuous theoretical curves for concentrationresponse relationships were constructed according to a modified Michaelis-Menten equation (1) using a least-squares fitting routine (Kijima \& Kijima, 1980):

$$
I=I_{\max } \frac{C^{\mathrm{n}}}{C^{\mathrm{n}}+\mathrm{EC}_{50}{ }^{\mathrm{n}}}
$$

where $I$ is the drug-induced current amplitude and $C$ is the corresponding drug concentration. $\mathrm{EC}_{50}$ and $\mathrm{n}$ denotes the half-maximum concentration and Hill slope, respectively. The equation for the concentration-inhibition curve is the mirror image of the Michaelis-Menten equation:

$$
I=1-\frac{C^{\mathrm{n}}}{C^{\mathrm{n}}+\mathrm{IC}_{50}{ }^{\mathrm{n}}}
$$

where $I$ is the current amplitude normalized by that of the control and $\mathrm{IC}_{50}$ denotes the half-inhibition concentration of antagonists.

\section{Solutions and their application}

The ionic composition of the standard external solution was (in $\mathrm{mM}$ ): $\mathrm{NaCl} 150, \mathrm{KCl} 5, \mathrm{MgCl}_{2} 1, \mathrm{CaCl}_{2} 2, \mathrm{~N}$-2-hydroxyethyl-piperazine-N'-2-ethanesulphonic acid (HEPES) 10 and glucose 10 . The $\mathrm{pH}$ was adjusted to 7.4 with tris (hydroxymethyl) aminomethane base (Tris-base). The ionic composition of the incubation medium was (in $\mathrm{mM}$ ): $\mathrm{NaCl} 125$, $\mathrm{KCl} 5, \mathrm{KH}_{2} \mathrm{PO}_{4} 1.2, \mathrm{MgSO}_{4} 1.3, \mathrm{CaCl}_{2} 2.4, \mathrm{NaHCO}_{3} 26$ and glucose 10 , aerated with $95 \% \mathrm{O}_{2}: 5 \% \mathrm{CO}_{2}$ gas to a final $\mathrm{pH}$ of 7.4. The ionic composition of the external solution with $10 \mathrm{mM} \mathrm{Ba}{ }^{2+}$ was (in $\mathrm{mM}$ ): $\mathrm{NaCl} 138, \mathrm{CsCl} 5, \mathrm{MgCl}_{2} 1$, $\mathrm{BaCl}_{2} 10$, HEPES 10 , glucose 10 and tetrodotoxin 0.001 . The pH was adjusted to 7.4 with Tris-base. The ionic composition of the pipette solution was (in $\mathrm{mM}$ ): $\mathrm{KCl} 150$ and HEPES 10 for recording the $\mathrm{ACh}$-induced current, and $\mathrm{CsCl} 150$ and HEPES 10 for recording the high-voltage activated $\mathrm{Ba}^{2+}$ current (HVA $I_{\mathrm{Ba}}$ ). The $\mathrm{pH}$ was adjusted to 7.2 with Trisbase. A fresh stock solution of $10 \mathrm{mg} \mathrm{ml}^{-1}$ nystatin in methanol was prepared every day and kept at $-20^{\circ} \mathrm{C}$. This was then dissolved into the pipette solution to produce a final nystatin concentration of $150 \mu \mathrm{g} \mathrm{ml}^{-1}$. The final pipette solution was made fresh every 2 or $3 \mathrm{~h}$.

Drugs were applied by a rapid application system termed the 'Y-tube' method, as described elsewhere (Murase et al., 1990). With the use of this technique, the solution surround- ing a dissociated neurone could be completely exchanged within 10 to $20 \mathrm{~ms}$.

\section{Drugs}

The drugs used in the present experiments were acetylcholine chloride $(\mathrm{ACh})$, muscarine chloride, nicotine, nystatin and thermolysin (Sigma), tetrodotoxin (TTX) (Sankyo), atropine sulphate (Merck), pertussis toxin (PTX) (Seikagaku Kougyo), pronase (Calbiochem), oxotremorine-M, 4-diphenylacetoxy$\mathrm{N}$-methylpiperidine (4-DAMP) methiodide and 4-(m-chlorophenylcarbamoyloxy)2-butynyltrimethylammonium chloride (McN-A-343) (RBI). 11-2[[2-[(dietylamino)methyl]-1-piperidinyl]acetyl]-5,11-dihydro-6H-pyrido[2,3-b][1,4]benzodiazepine6-one (AF-DX-116) was kindly given by Prof. T. Kamiya (Fukuoka University, Japan). All drugs were dissolved in external solution just before use.

\section{Results}

\section{ACh-induced currents}

In the perforated patch recording configuration, $10^{-5} \mathrm{M} \mathrm{ACh}$ evoked a net inward current $\left(I_{\mathrm{ACh}}\right)$ associated with a 30 to $60 \%$ decrease in membrane conductance in 75 out of 110 cortical pyramidal neurones at a holding potential $\left(\mathrm{V}_{\mathrm{H}}\right)$ of $-40 \mathrm{mV}$ (Figure 1a, upper panel). The inward currents were long-lasting and typically persisted for 4 to $5 \mathrm{~min}$ after the application of ACh for 30 to $40 \mathrm{~s}$. The lower panel in Figure la illustrates the effect of ACh on currents evoked by $300 \mathrm{~ms}$ hyperpolarizing step pulses from -40 to $-50 \mathrm{mV}$. The step pulse represented a leak current plus the M-current ( $I_{M}$; Brown \& Adams, 1980; Constanti \& Brown, 1981) before the application of ACh. During the steady-state of $I_{\mathrm{ACh}}$, the step pulse represented the deactivation of $I_{M}$. The $I_{M}$ was reactivated by the removal of ACh. A small transient outward current was observed in 35 out of 110 neurones $(31.8 \%)$, which was followed by a slow inward current (Figure 1b).

During the perforated patch whole-cell recording, the application of $\mathrm{ACh}$ at $10 \mathrm{~min}$ intervals could elicit $I_{\mathrm{ACb}}$ with stable current amplitudes over $1 \mathrm{~h}$ (Figure 1c(i)), whereas the conventional whole-cell recording (Akaike et al., 1978; Hamill et al., 1981) caused a considerable 'run-down' of $I_{\mathrm{ACh}}$ within $15 \mathrm{~min}$ after rupture of the membrane patch (Figure $1 \mathrm{c}(\mathrm{ii}))$. It is known that $I_{M}$ in rat sympathetic ganglion cells slowly declines over a period of $15 \mathrm{~min}$ in a conventional whole-cell patch recording (Brown et al., 1989). ATP added to the pipette solution can reduce the run-down (Pfaffinger, 1988). However, this may alter the responsiveness for ACh since the muscarinic ACh response is mediated by multiple steps of the intracellular signal transduction system. In the present study, therefore, the nystatin perforated patch recording configuration was used in subsequent experiments to prevent wash-out of the $\mathrm{ACh}$ response.

\section{Current-voltage (I-V) relationship for $A C h$ response}

The concentrations of $\mathrm{K}^{+}$in the external and internal (pipette) solutions were 5 and $150 \mathrm{mM}$, respectively. The voltage-dependent $\mathrm{Ca}^{2+}$ and $\mathrm{Na}^{+}$channels were suppressed by adding $10^{-5} \mathrm{M} \mathrm{La}^{3+}$ and $10^{-6} \mathrm{M}$ tetrodotoxin, respectively. Figure $2 \mathrm{a}$ illustrates the inward currents evoked by $10^{-5} \mathrm{M}$ $A C h$ at various $V_{H} s$. As shown in Figure $2 a$ and summarized in Figure $2 \mathrm{~b}$, the $I_{\mathrm{ACh}}$ had distinct voltage-dependency. The $I_{\mathrm{ACh}}$ increased as the membrane depolarized and was not observed at potentials more negative than $-80 \mathrm{mV}$ without showing any reversal of current direction, being consistent with that of $I_{\mathrm{M}}$. Figure 2c shows the current-voltage $(I-V)$ relationships to asymmetrical hyperpolarizing ramp voltage between -20 and $-100 \mathrm{mV}$ from a $\mathrm{V}_{\mathrm{H}}$ of $-40 \mathrm{mV}$, before (control) and during the application of ACh. In this case, the $I-V$ property was also identical to that of $I_{M}$. 
a

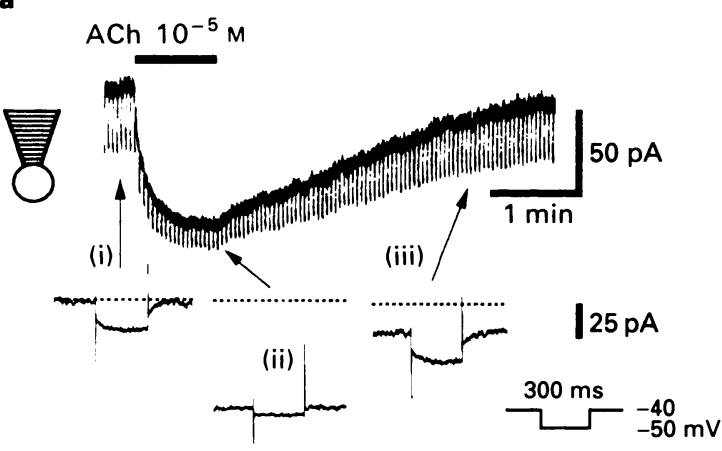

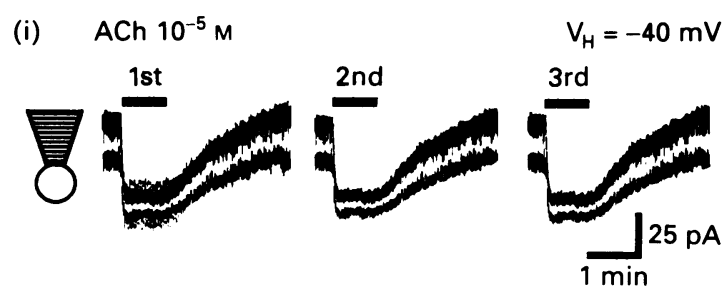

(ii)

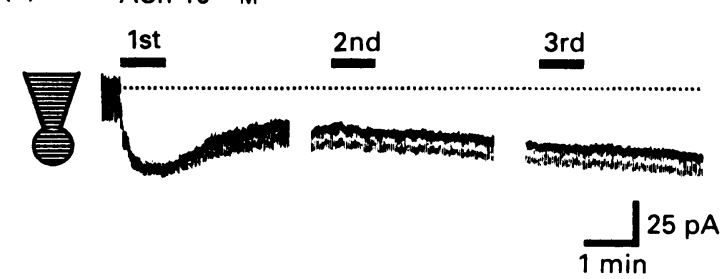

Figure 1 Effects of $\mathrm{ACh}\left(10^{-5} \mathrm{M}\right)$ on the pyramidal neurones freshly dissociated from the rat cerebral cortex. (a) ACh-induced inward current $\left(I_{\mathrm{ACh}}\right)$ recorded by the nystatin perforated patch technique. The neurone was held at a holding potential ( $\left.\mathrm{V}_{\mathrm{H}}\right)$ of $-40 \mathrm{mV}$ and a brief hyperpolarizing pulse of $10 \mathrm{mV}$ with $300 \mathrm{~ms}$ duration was applied every $2 \mathrm{~s}$. ACh was applied during the period indicated by the horizontal bar above each current recording. Inward current relaxations produced by a hyperpolarizing voltage command from -40 to $-50 \mathrm{mV}$, before, during and after the application of $10^{-5} \mathrm{MACh}$ are expanded for detail and shown in the lower panel of (a). (b) ACh elicited a small transient outward current followed by a long-lasting inward current in $31.8 \%$ of neurones tested. (c) (i) In nystatin perforated patch mode, $I_{\mathrm{ACh}}$ was constantly recorded by successive applications of $\mathrm{ACh}$. (c) (ii) $I_{\mathrm{ACh}}$ recorded in the conventional whole-cell mode at a $\mathrm{V}_{\mathrm{H}}$ of $-40 \mathrm{mV}$. The $I_{\mathrm{ACh}}$ showed run-down with time. Recordings (i) and (ii) were obtained from different neurones.
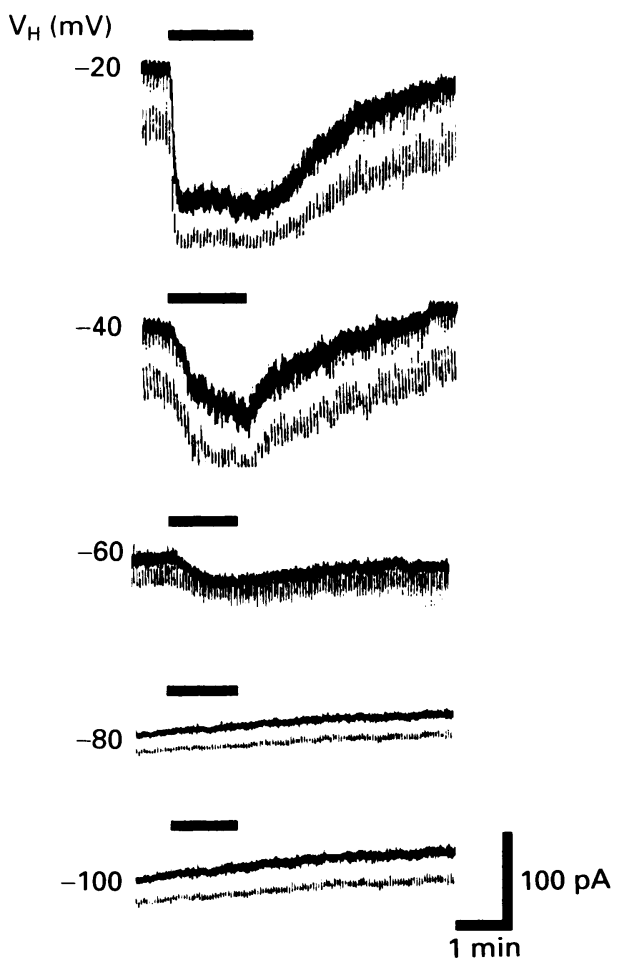

b

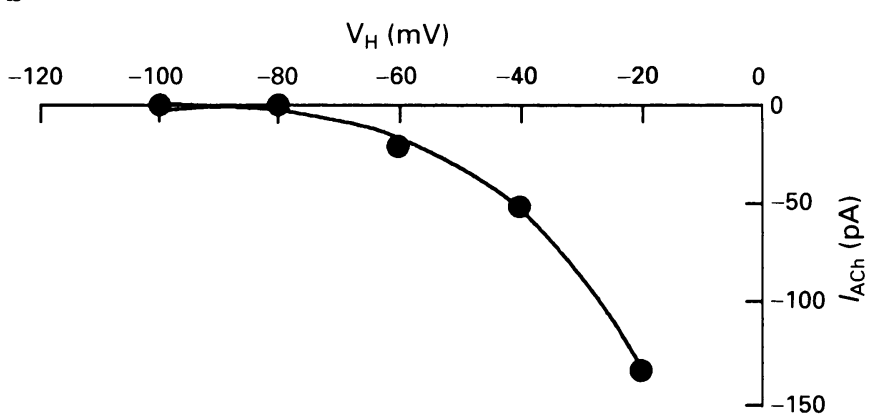

c

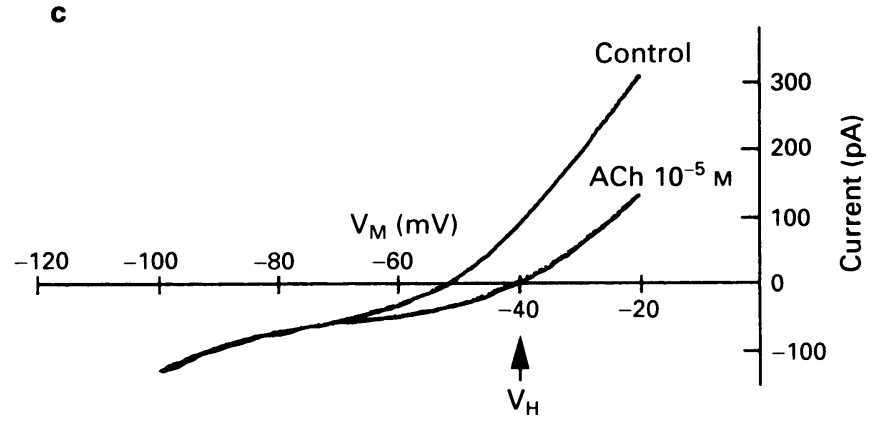

Figure $2 \mathrm{ACh}$ response and its current-voltage (I-V) relationship. (a) ACh-induced currents at various $\mathrm{V}_{\mathrm{H}} \mathrm{s}$. Horizontal bars indicate the period of application of $10^{-5} \mathrm{M} \mathrm{ACh}$. (b) $I-V$ relationship of the $I_{\mathrm{ACh}}$ at various $\mathrm{V}_{\mathrm{H}} \mathrm{s}$. The data were obtained from (a). Similar results were obtained from five cells. (c) $I-V$ relationships obtained by ramp-commands between -20 and $-100 \mathrm{mV}$ in $2 \mathrm{~s}$ in the presence or absence of $10^{-5} \mathrm{M} A C h$. $\mathrm{V}_{\mathrm{M}}$; membrane potential. Similar results were obtained from six cells. 


\section{Concentration-response relationships for $A C h$ and its agonists}

Figure 3a(i) and (ii) show typical inward currents induced by $\mathrm{ACh}$ and muscarine of various concentrations at $a \mathrm{~V}_{\mathrm{H}}$ of $-40 \mathrm{mV}$, respectively. Nicotine evoked no response at concentrations up to $10^{-3} \mathrm{M}$. Figure $3 \mathrm{~b}$ summarizes the concentration-response relationships for $\mathrm{ACh}$ and its agonists. The $\mathrm{ACh}$ and muscarine responses increased in a concentrationdependent manner. Muscarine was approximately 10 times less potent than $\mathrm{ACh}$. The half maximum concentration $\left(\mathrm{EC}_{50}\right)$ of $\mathrm{ACh}$ in the concentration-response curve was $8.7 \times 10^{-7} \mathrm{M}$. The Hill coefficient was 0.9 . The $E_{50}$ value and Hill coefficient of the muscarine response were $8.6 \times$ $10^{-6} \mathrm{M}$ and 0.8 , respectively. These results suggest that the $\mathrm{ACh}$ response is mediated by the muscarinic $\mathrm{ACh}$ receptors. Therefore, the effects of muscarinic agonists such as McN-A343 , oxotremorine and oxotremorine-M were tested in the cortical pyramidal neurones. Figure $3 a$ (iii) shows the inward currents evoked by McN-A-343 in a concentration-dependent manner. Figure $3 \mathrm{~b}$ also summarizes the concentration-response relationships for $\mathrm{McN}-\mathrm{A}-343$ and two other muscarinic agonists. The $\mathrm{EC}_{50}$ of $\mathrm{McN}-\mathrm{A}-343$ was $4.5 \times 10^{-6} \mathrm{M}$. Oxotremorine, a cardiac $\mathbf{M}_{2}$ agonist (Brann et al., 1987), was about 30 times less potent than muscarine. The order of potency was $\mathrm{ACh}>$ oxotremorine-M $>\mathrm{McN}-\mathrm{A}-343 \geqslant$ muscarine $>$ oxotremorine.

\section{Effects of muscarinic antagonists}

The effects of muscarinic antagonists (atropine, pirenzepine, 4-DAMP and AF-DX-116) on the $I_{\mathrm{ACh}}$ were examined.
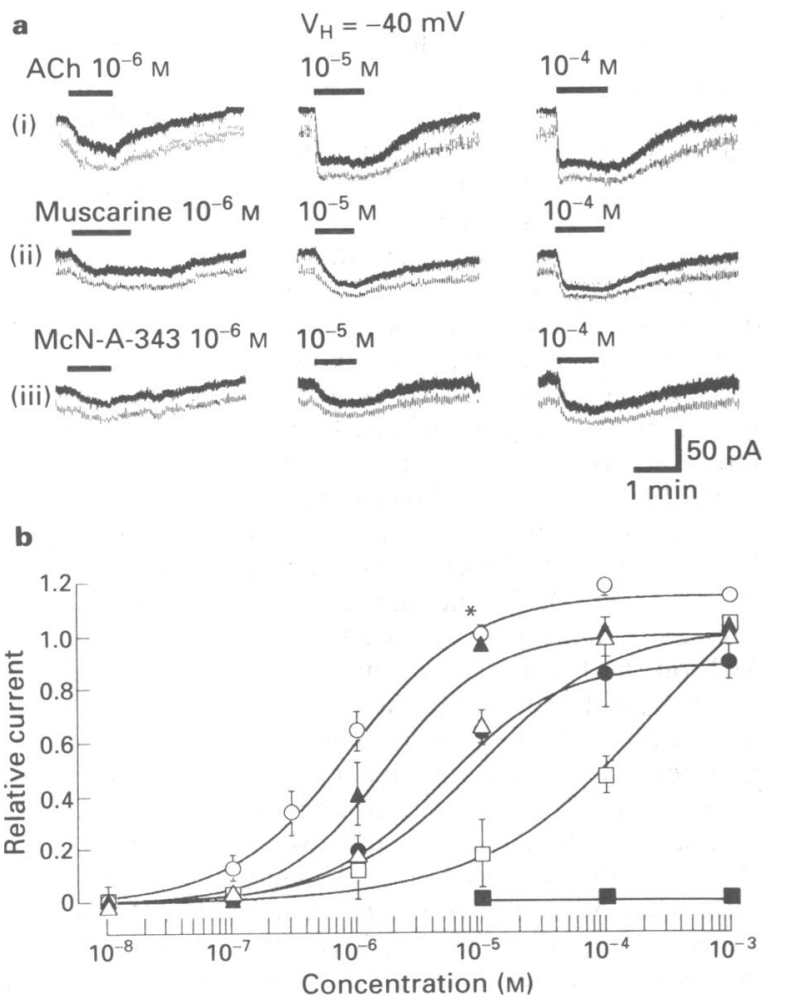

Figure 3 Concentration-response relationships for ACh agonists. (a) The inward currents induced by ACh, muscarine and McN-A-343 of various concentrations at a $V_{H}$ of $-40 \mathrm{mV}$. The neurones were exposed to each agonist for the period indicated by a horizontal bar. (b) Concentration-response relationships for the peak inward current induced by $\mathrm{ACh}(\mathrm{O})$, muscarine $(\Delta), \mathrm{McN}-\mathrm{A}-343(\mathrm{O})$, oxotremorine $(\square)$ and oxotremorine-M $(\Delta)$. Nicotine $(\square)$ elicited no response. All currents were normalized to the peak current amplitude induced by $10^{-5} \mathrm{M}\left({ }^{*}\right)$. Each point represents the mean ( \pm s.e.mean) of six to eight neurones.
Pirenzepine shifted the concentration-response curve for $\mathrm{ACh}$ to the right. Figure $4 a(i)$ shows the concentration-response relationships for $\mathrm{ACh}$ obtained under control condition $(0)$, and in the presence of $10^{-7}(\Delta), 3 \times 10^{-7}(\diamond)$ and $10^{-6} \mathrm{M}$ (ם) pirenzepine $\left(n=4-5\right.$ in each case), with $\mathrm{EC}_{50}$ values of $8.49 \times 10^{-7}, 7.17 \times 10^{-6}, 1.64 \times 10^{-5}$ and $7.64 \times 10^{-5} \mathrm{M}$, respectively. Figure $4 \mathrm{a}$ (ii) illustrates the corresponding Schild plot (Arunlakshana \& Schild, 1959). The estimated $\mathrm{pA}_{2}$ value was 7.81. Figure $4 \mathrm{~b}$ summarizes the concentration-inhibition curves of various antagonists on $I_{\mathrm{ACh}}$ elicited by $10^{-5} \mathrm{M} \mathrm{ACh}$. Atropine, pirenzepine, 4-DAMP and AF-DX-116 reversibly blocked $I_{\mathrm{ACh}}$ in a concentration-dependent manner. The halfinhibition concentrations $\left(\mathrm{IC}_{50}\right)$ were $2.49 \times 10^{-9} \mathrm{M}$ for atropine, $1.18 \times 10^{-8} \mathrm{M}$ for 4-DAMP, $2.07 \times 10^{-7} \mathrm{M}$ for pirenzepine and $3.35 \times 10^{-6} \mathrm{M}$ for AF-DX-116.

\section{Effect of pertussis toxin (PTX)}

It is well established that muscarinic receptors are linked to G-proteins (Bonner, 1989). To investigate what kind of Gproteins may mediate the $I_{\mathrm{ACh}}$, the dissociated cortical neurones were incubated in standard external solution with or without PTX $200 \mathrm{ng} \mathrm{ml}^{-1}$ for $8 \mathrm{~h}$, because PTX is able to ADP-ribosylate the $\alpha$-subunit of $G_{i}$ and $G_{0}$ proteins, resulting in the inhibition of their activation by the receptors (Kurose et al., 1983; Murayama \& Ui, 1983). The PTX-treated and non-treated neurones were voltage-clamped at a $V_{H}$ of $-40 \mathrm{mV}$ and tested with $10^{-5} \mathrm{M} \mathrm{ACh}$. The amplitude and response pattern of $I_{\mathrm{ACh}}$ in the PTX-treated neurones did not differ from those of the control without PTX treatment (Figure 5a, $n=8$ ). To ensure that PTX was effective, the effect of $\mathrm{ACh}$ on the high-voltage activated $\mathrm{Ba}^{2+}$ inward a
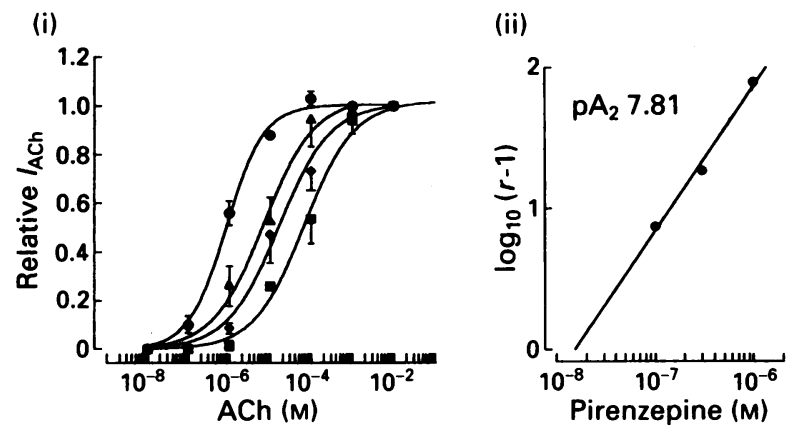

b

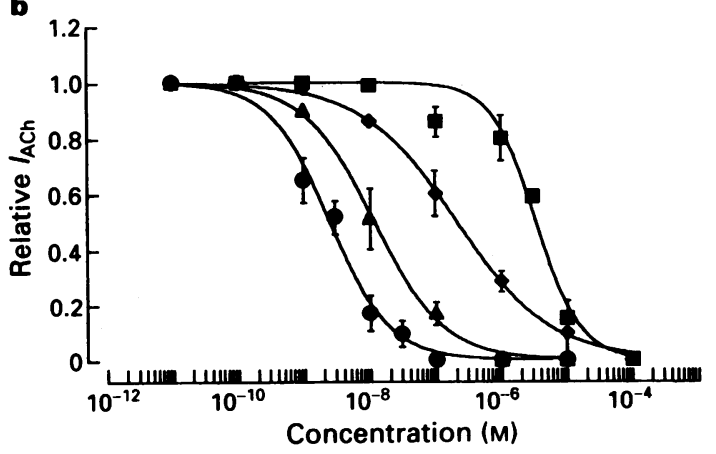

Figure 4 Effects of muscarinic antagonists on $I_{\mathrm{ACh}}$. (a) (i) Shift of the concentration-response curves for $\mathrm{ACh}(\mathrm{O})$ by $10^{-7}(\mathrm{~A})$, $3 \times 10^{-7}(\diamond)$ and $10^{-6} \mathrm{M}(\square)$ pirenzepine. (ii) Corresponding Schild plot where $r$ is the agonist concentration ratio. The line was fitted by linear regression and yielded a $\mathrm{pA}_{2}$ for pirenzepine of 7.81 with a unconstrained slope of $1.07\left(R^{2}=0.99\right)$. (b) Concentration-dependent inhibition curves of $I_{A C h}$ in the presence of atropine (O), 4-DAMP $(\Delta)$, pirenzepine $(\diamond)$ and AF-DX-116 (a). Neurones were pretreated for 2 min with each antagonist. Each symbol represents the mean ( \pm s.e.mean) of five to seven neurones. 
a

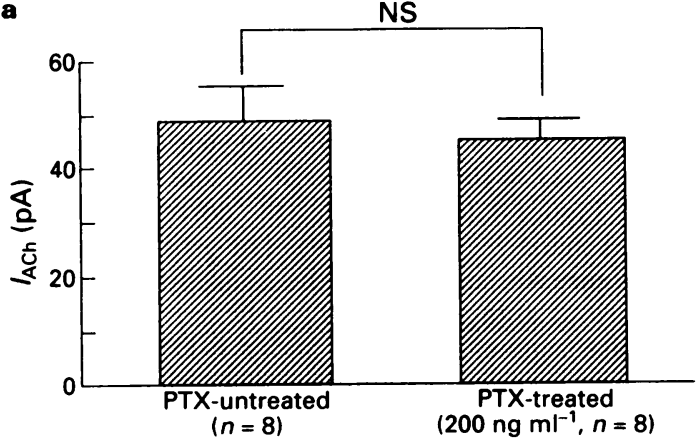

$\mathbf{b}$

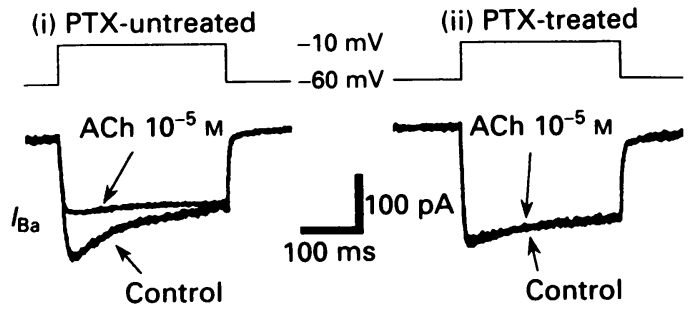

Figure 5 Effects of pertussis toxin (PTX) on $I_{\mathrm{ACh}}$ and HVA $I_{\mathrm{Ba}}$. (a) Dissociated neurones were immersed in external solution with or without PTX for $8 \mathrm{~h}$. NS: no significant difference. $n$ : the number of neurones tested. (b) HVA $I_{\mathrm{Ba}}$ was evoked by a $300 \mathrm{~ms}$ step pulse to $-10 \mathrm{mV}$ from a $\mathrm{V}_{\mathrm{H}}$ of $-60 \mathrm{mV}$. In these experiments, neurones were pretreated with $\mathrm{ACh}$ for at least $2 \mathrm{~min}$. (b) (i) $\mathrm{ACh} 10^{-5} \mathrm{M}$ suppressed HVA $I_{\mathrm{Ba}}$ in neurones without PTX treatment. (ii) $\mathrm{ACh}$ had no effect on HVA $I_{\mathrm{Ba}}$ in neurones treated with $200 \mathrm{ng} \mathrm{ml}^{-1}$ PTX for $8 \mathrm{~h}(n=12)$.

current (HVA, $I_{\mathrm{Ba}}$ ) passing through the $\mathrm{Ca}^{2+}$ channel was simultaneously examined in $\mathrm{K}^{+}$-free $\mathrm{Cs}^{+}$external solution containing $10 \mathrm{mM}-\mathrm{Ba}^{2+}$ in the presence or absence of PTX (Figure 5b). The HVA $I_{\mathrm{Ba}}$ was induced by a $300 \mathrm{~ms}$ depolarizing command step to $-10 \mathrm{mV}$ from a $\mathrm{V}_{\mathrm{H}}$ of $-60 \mathrm{mV}$, at which potential the low-voltage activated $\mathrm{Ca}^{2+}$ channel was inactivated (Akaike et al., 1989). Here, $10^{-5} \mathrm{M}$ ACh suppressed the activation phase of $I_{\mathrm{Ba}}$ in control neurones $8 \mathrm{~h}$ after the dissociation $(n=8)$, whereas ACh had no effect on $I_{\mathrm{Ba}}$ in neurones treated with PTX for $8 \mathrm{~h}$ $(n=12)$.

\section{Discussion}

In the present study, $\mathrm{ACh}$ induced a long-lasting net inward current $\left(I_{\mathrm{ACh}}\right)$ in rat cortical pyramidal neurones. This inward current resulted from the decrease in a voltage- and timedependent $\mathrm{K}^{+}$conductance known as the $\mathrm{M}$-current $\left(I_{\mathrm{M}}\right.$; Brown \& Adams, 1980). This reduction of $I_{M}$ is widely observed in various neurones such as neurones in the sympathetic ganglia (Brown \& Adams, 1980; Constanti \& Brown, 1981), the hippocampus (Benardo \& Prince, 1982; Halliwell \& Adams, 1982), the cerebral cortex (McCormick \& Prince, 1985; Constanti \& Sim, 1987) and the amygdala (Womble \& Moises, 1992). The inhibition of $I_{M}$ by ACh in these neurones may greatly enhance the neuronal excitability, thereby regulating functions of neuronal systems.

Molecular cloning studies have identified five genes for muscarinic $\mathrm{ACh}$ receptors denoted as $\mathrm{m} 1-\mathrm{m} 5$ (Bonner et al., 1988) and the receptors expressed for $\mathrm{m} \mathrm{1-m4}$ may correspond pharmacologically to $\mathbf{M}_{1}-\mathbf{M}_{4}$ (Hulme et al., 1990). Although muscarinic receptors cannot be differentiated exclusively with the agonists and antagonists, the receptors do show different sensitivity to these drugs. In the present study, pirenzepine effectively inhibited $I_{\mathrm{ACh}}$, and the $\mathrm{pA}_{2}$ value for pirenzepine was 7.81. This high affinity of pirenzepine is closer to those of $\mathbf{M}_{1}$ and $\mathbf{M}_{4}$ than that of $\mathbf{M}_{2}$, $M_{3}$ and the receptor expressed for $m$ 5. Atropine, 4-DAMP and AF-DX-116 also suppressed $I_{\mathrm{ACh}}$. The sensitivity of $I_{\mathrm{ACh}}$ to these antagonists was in the order of atropine $>4$ DAMP $>$ pirenzepine $>$ AF-DX-116, whereas AF-DX-116 has higher affinity for $\mathbf{M}_{2}$ than pirenzepine (Micheletti et al., 1987; Buckley et al., 1989). Oxotremorine, the cardiac $\mathbf{M}_{2}$ agonist, could induce inward current only at high concentrations. Thus, $\mathbf{M}_{2}$ was not involved in the present response. McN-A-343 is functionally potent in stimulating the $\mathbf{M}_{1}$ receptor and has less activity at $\mathbf{M}_{2}$ and $\mathbf{M}_{3}$, though this compound displays little selectivity for muscarinic receptors in the binding assay (Birdsall et al., 1983; Freedman et al., 1988; Lambrecht et al., 1993). McN-A-343 mimicked the $\mathrm{ACh}$ response in the present preparation, while this agonist could not activate $\mathrm{M}_{3}$ in CAl pyramidal neurones (Wakamori et al., 1993). Therefore, the candidate subtypes responsible for the $I_{\mathrm{ACb}}$ may be $\mathrm{M}_{1}$ or $\mathbf{M}_{4}$. In transfected NG108-15 cells, expressed receptors for $\mathrm{m} 1$ and $\mathrm{m} 3$ are capable of inhibiting $I_{M}$, while $\mathrm{m} 2$ and $\mathrm{m} 4$ are not (Fukuda et al., 1988; Robbins et al., 1991). In rat sympathetic ganglion cells $M_{1}$ also could couple to $I_{M}$ but $M_{4}$ could not (Marrion et al., 1989; Bernheim et al., 1992). In addition, $\mathbf{M}_{4}$ is known to link to PTX-sensitive G-protein, while the present response was PTX-insensitive. Taking these facts into account, the $\mathbf{M}_{1}$ subtype may be predominantly responsible for the reduction of $I_{M}$ in rat cortical pyramidal neurones. Immunocytochemistry (Levey et al., 1991; Wall et al., 1991) and in situ hybridization studies (Buckley et al., 1988) showed the presence of multiple subtypes of muscarinic ACh receptors in the rat neocortex. The $\mathrm{ml}$ subtype, most abundant in this brain area, may regulate $I_{\mathrm{M}}$. The $\mathrm{m} 2$ protein was also recognized by immunocytochemistry, whereas mRNA for the $\mathrm{m} 2$ gene is low. This is consistent with the suggestion that this subtype possibly functions as an autoreceptor at the ends of cholinergic fibres projected from the basal forebrain (Levey et al., 1991). The proteins and mRNA for $\mathrm{m} 3$ and $\mathrm{m} 4$ were also detected. Although the $M_{3}$ receptor can be involved in the regulation of $I_{M}$ (Fukuda et al., 1988; Robbins et al., 1991) and $\mathbf{M}_{4}$ can be coupled to the high-voltage-activated (HVA) $\mathrm{Ca}^{2+}$ channel (Bernheim et al., 1992), the functional significances of these subtypes in the cortex remain to be elucidated.

Multiple G-proteins are known to mediate the muscarinic $\mathrm{ACh}$ responses. The receptors expressed for $\mathrm{m} 1, \mathrm{~m} 3$ and $\mathrm{m} 5$ link to a PTX-insensitive G-protein and regulate inositol phospholipid hydrolysis, whereas those for $\mathrm{m} 2$ and $\mathrm{m} 4$ inhibited adenylyl cyclase through PTX-sensitive G-protein (Bonner, 1989). In electrophysiological studies, the inhibition of $I_{M}$ in various types of neurones is PTX-insensitive (Dutar \& Nicoll, 1988; Pfaffinger, 1988; Brown et al., 1989; Bernheim et al., 1992). In the present study, the $I_{\mathrm{ACh}}$ was not suppressed by treatment with PTX, while the inhibitory effect of ACh on the HVA Ca ${ }^{2+}$ channel was abolished, suggesting that the present muscarinic $\mathrm{ACh}$ receptor also regulated $I_{\mathrm{M}}$ via PTX-insensitive G-protein, while the $\mathrm{HVA} \mathrm{Ca}{ }^{2+}$ channel is operated by a PTX-sensitive G-protein. Recently, Bernheim et al. (1992) demonstrated that $\mathbf{M}_{1}$ and $\mathbf{M}_{4}$ coexist in rat sympathetic neurones and that $M_{1}$ suppresses $I_{M}$ and the HVA $\mathrm{Ca}^{2+}$ current (HVA $I_{\mathrm{Ca}}$ ) through PTX-insensitive Gprotein, while $\mathrm{M}_{4}$ inhibited the HVA $I_{\mathrm{Ca}}$ with a PTX-sensitive G-protein. Thus, the PTX-sensitive muscarinic inhibition of the HVA $\mathrm{Ca}^{2+}$ channel in cortical pyramidal neurones may be also mediated by another co-existing receptor subtype such as $\mathbf{M}_{2}$ or $\mathbf{M}_{4}$ rather than by $\mathbf{M}_{1}$. In the present study, a PTX-insensitive reduction of the $\mathrm{HVA} \mathrm{Ca}{ }^{2+}$ channel was not observed. This may reflect differences between species or the brain region.

Of the neurones tested, $31.8 \%$ showed a small transient outward current, although its physiological implication is unknown. In hippocampal CAl neurones, many inositol hydrolysis-mediated responses were accompanied by a transient outward $\mathrm{K}^{+}$current (Uneyama et al., 1993; Wakamori et al., 
1993; Shirasaki et al., 1994). Here, ACh and 5-hydroxytryptamine facilitated inositol triphosphate formation and thereby mobilized $\mathrm{Ca}^{2+}$ from intracellular stores. Then, $\mathrm{Ca}^{2+}$ calmodulin-dependent protein kinase activated a $\mathrm{K}^{+}$conductance, resulting in an outward current. In the cortical region, $\mathrm{ACh}$ facilitated inositol hydrolysis via a muscarinic receptor with high affinity for pirenzepine, possibly $\mathbf{M}_{1}$ (Downes, 1982). Hence, the present outward current may be activated through the inositol hydrolysis pathway.

Alzheimer's disease is considered to be associated with a marked depletion of cortical acetylcholinesterase and the loss of cortical cholinergic innervation (Mesulam \& Geula, 1988).
Furthermore, $\mathbf{M}_{1}$-selective antagonists impair memory in animals (Messer et al., 1990). Therefore, the understanding of the actions of $\mathrm{ACh}$ on cortical pyramidal neurones may facilitate the development of pharmacological therapies for Alzheimer's disease and other neurological disorders in this brain area.

This study was supported by Grant-in-Aid for Scientific Research (Nos. 03304026, 0404429 and 04404023 ) to N.A. from the Ministry of Education, Science and Culture, Japan.

\section{References}

AKAIKE, N., KOSTYUK, P.G. \& OSIPCHUK, Y.V. (1989). Dihydropyridine-sensitive low-threshold calcium channels in isolated rat hypothalamic neurones. J. Physiol., 412, 181-195.

AKAIKE, N., LEE, K.S. \& BROWN, A.M. (1978). The calcium current of Helix neurone. J. Gen. Physiol., 71, 509-531.

ARUNLAKSHANA, O. \& SCHILD, H.O. (1959). Some quantitative uses of drug antagonists. Br. J. Pharmacol. Chemother., 14, 48-58.

BENARDO, L.S. \& PRINCE, D.A. (1982). Cholinergic excitation of mammalian hippocampal pyramidal cells. Brain Res., 249, 315331.

BERNHEIM, L., MATHIE, A. \& HILLE, B. (1992). Characterization of muscarinic receptor subtypes inhibiting $\mathrm{Ca}^{2+}$ current and $\mathrm{M}$ current in rat sympathetic neurons. Proc. Natl. Acad. Sci. U.S.A., 89, 9544-9548

BIRDSALL, N.J.M., BURGEN, A.S.V., HULME, E.C. \& STOCKTON, J.M. (1983). The effect of McN-A-343 on muscarinic receptors in the cerebral cortex and heart. Br. J. Pharmacol., 78, 257-259.

BONNER, T.I. (1989). The molecular basis of muscarinic receptor diversity. Trends Neurosci., 12, 148-151.

BONNER, T.I., YOUNG, A.C., BRANN, M.R. \& BUCKLEY, N.J. (1988), Cloning and expression of the human and rat $\mathrm{m} 5$ muscarinic acetylcholine receptor genes. Neuron, 1, 403-410.

BRANN, M.R., BUCKLEY, N.J., JONES, S.V.P. \& BONNER, T.I. (1987). Expression of a cloned muscarinic receptor in A9 L cells. Mol. Pharmacol., 32, 450-455.

BROWN, D.A. \& ADAMS, P.R. (1980). Muscarinic suppression of a novel voltage-sensitive $\mathrm{K}^{+}$-current in a vertebrate neurone. Nature, 283, 673-676.

BROWN, D.A., MARRION, N.V. \& SMART, T.G. (1989). On the transduction mechanism for muscarine-induced inhibition of $\mathbf{M}$ current in cultured rat sympathetic neurones. J. Physiol., 413, $469-488$.

BUCKLEY, N.J., BONNER, T.I. \& BRANN, M.R. (1988). Localization of a family of muscarinic receptor mRNAs in rat brain. $J$. Neurosci., 8, 4646-4652.

BUCKLEY, N.J., BONNER, T.I., BUCKLEY, C.M. \& BRANN, M.R (1989). Antagonist binding properties of five cloned muscarinic receptors expressed in CHO-K1 cells. Mol. Pharmacol., 35, 469-476.

CONSTANTI, A. \& BROWN, D.A. (1981). M-currents in voltageclamped mammalian sympathetic neurones. Neurosci. Lett., 24, 289-294.

CONSTANTI, A. \& SIM, J.A. (1987). Muscarinic receptors mediating suppression of the M-current in guinea-pig olfactory cortex neurones may be of the $\mathbf{M}_{2}$-subtype. Br. J. Pharmacol., 90, 3-5.

COYLE, J.T., PRICE, D.L. \& DELONG, M.R. (1983). Alzheimer's disease: a disorder of cortical cholinergic innervation. Science, 219, $1184-1190$.

DOWNES, C.P. (1982). Receptor-stimulated inositol phospholipid metabolism in the central nervous system. Cell Calcium, 3, 413-428.

DUTAR, P. \& NICOLL, R.A. (1988). Classification of muscarinic responses in hippocampus in terms of receptor subtypes and second messenger systems: electrophysiological studies in vitro. J. Neurosci., 8, 4214-4224.

FREEDMAN, S.B., BEER, M.S. \& HARLEY, E.A. (1988). Muscarinic $\mathbf{M}_{1}, \mathbf{M}_{2}$ receptor binding. Relationship with functional efficacy. Eur. J. Pharmacol., 156, 133-142.

FUKUDA, K., HIGASHIDA, H., KUBO, T., MAEDA, A., AKIBA, I., BUJO, H., MISHINA, M. \& NUMA, S. (1988). Selective coupling with $\mathrm{K}^{+}$currents of muscarinic acetylcholine receptor subtypes in NG108-15 cells. Nature, 335, 355-358.

HALLIWELL, J.V. \& ADAMS, P.R. (1982). Voltage-Clamp analysis of muscarinic excitation in hippocampal neurons. Brain Res., 250, $71-92$

HAMILL, J.V., MARTY, A., NEHER, E., SAKMANN, B. \& SIGWORTH F.J. (1981). Improved patch-clamp techniques for high-resolution current recording from cells and cell-free membrane patches. Pflügers Arch., 391, 85-100.

HULME, E.C., BIRDSALL, N.J.M. \& BUCKLEY, N.J. (1990). Muscarinic receptor subtypes. Annu. Rev. Pharmacol. Toxicol., 30, 633-673.

ITO, C., WAKAMORI, M. \& AKAIKE, N. (1991). Dual effect of glycine on isolated rat suprachiasmatic neurons. Am. J. Physiol., 260, C213-C218.

KIJIMA, H. \& KIJIMA, S. (1980). Cooperative response of chemically excitable membrane. II. Two state models and their limitations. J. Theor. Biol., 82, 425-463.

KRNJEVIC, K. (1974). Chemical nature of synaptic transmission in vertebrates. Physiol. Rev., 54, 418-540.

KRNJEVIC, K., PUMAIN, R. \& RENAUD, L. (1971). The mechanism of excitation by acetylcholine in the cerebral cortex. J. Physiol., 215, 247-268.

KUROSE, H. KATADA, T. AMANO, T, \& UI, M. (1983). Specific uncoupling by islet-activating protein, pertussis toxin, of negative signal transduction via $\alpha$-adrenergic, cholinergic, and opiate receptors in neuroblastoma $\times$ glioma hybrid cells. J. Biol. Chem., 258, 4870-4875.

LAMBRECHT, G., MOSER, U., GRIMM, U., PFAFF, O., HERMANNI, U., HILDEBRANDT, C., WAELBROECK, M., CHRISTOPHE, J. \& MUTSCHLER, E. (1993). New functionally selective muscarinic agonists. Life Sci., 52, 481-488.

LAZARENO, S., BUCKLEY, N.J. \& ROBERTS, F.F. (1990). Characterization of muscarinic $\mathbf{M}_{4}$ binding sites in rabbit lung, chicken heart and NG108-15 cell. Mol. Pharmacol., 38, 805-815.

LEVEY, A.I., KITT, C.A., SIMONDS, W.F., PRINCE, D.L. \& BRANN M.R. (1991). Identification and localization of muscarinic acetylcholine receptor proteins in brain with subtype-specific antibodies. J. Neurosci., 11, 3218-3226.

MARRION, N.V., SMART, T.G., MARSH, S.J. \& BROWN, D.A. (1989). Muscarinic suppression of the M-current in the rat sympathetic ganglion is mediated by receptors of the $\mathrm{M}_{1}$-subtype. Br. $J$. Pharmacol., 98, 557-573.

MCCORMICK, D.A. \& PRINCE, D.A. (1985). Two types of muscarinic response to acetylcholine in mammalian cortical neurones. Proc. Natl. Acad. Sci. U.S.A., 82, 6344-6348.

MCKINNEY, M. \& RICHELSON, E. (1984). The coupling of the neuronal muscarinic receptor to responses. Annu. Rev. Pharmacol. Toxicol., 24, 121-146.

MESSER, W.S., BOHNETT, M. \& STIBBE, J. (1990). Evidence for a preferential involvement of $M 1$ muscarinic receptors in representational memory. Neurosci. Lett., 116, 184-189.

MESULAM, M.M. \& GEULA, C. (1988). Nucleus Basalis (ch4) and cortical cholinergic innervation in the human brain: observations based on the distribution of acetylcholinesterase and choline acetyltransferase. J. Comp. Neurol., 275, 216-240.

MICHELETTI, R., MONTAGNA, E. \& GIACHETTI, A. (1987). AFDX 116, a cardioselective muscarinic antagonist. J. Pharmacol. Exp. Ther., 241, 628-634.

MURASE, K., RANDIC, M., SHIRASAKI, T., NAKAGAWA, T. \& AKAIKE, N. (1990). Serotonin suppresses N-methyl-D-aspartate responses in acutely isolated spinal dorsal horn neurons of the rat. Brain Res., 525, 84-91. 
MURAYAMA, T. \& UI, M. (1983). Loss of the inhibitory function of the guanine nucleotide regulatory component of adenylate cyclase due to its ADP ribosylation by islet-activating protein, pertussis toxin, in adipocyte membranes. J. Biol. Chem., 258, 3319-3326.

PFAFFINGER, P.J. (1988). Muscarine and t-LHRH suppress Mcurrent by activating an IAP-insensitive G-protein. J. Neurosci., 8, 3343-3353.

ROBBINS, J., CAULFIELD, M.P., HIGASHIDA, H. \& BROWN, D.A. (1991). Genotypic m3-muscarinic receptors preferentially inhibit M-currents in DNA-transfected NG108-15 neuroblastoma $\times$ Glioma hybrid cells. Eur. J. Neurosci., 3, 820-824.

SHIRASAKI, T., HARATA, N. \& AKAIKE, N. (1994). Metabotropic glutamate response in acutely dissociated hippocampal CA1 pyramidal neurones of the rat. J. Physiol., 475, 439-453.

SQUIRE, L.R. \& DAVIS, H.P. (1981). The pharmacology of memory: a neurobiological perspective. Annu. Rev. Pharmacol., 21, 323356.
UNEYAMA, H., UENO, S. \& AKAIKE, N. (1993). Serotonin-operated potassium current in CAl neurones dissociated from rat hippocampus. J. Neurophysiol., 69, 1044-1052.

WAKAMORI, M., HIDAKA, H. \& AKAIKE, N. (1993). Hyperpolarizing muscarinic responses of freshly dissociated rat hippocampal CA1 neurones. J. Physiol., 463, 585-604.

WALL, S.J., YASUDA, R.P., HORY, F., FLAGG, S., MARTIN, B.M. \& GINNS, E.I. (1991). Production of antisera selective for $\mathrm{ml}$ muscarinic receptors using fusion proteins: distribution of $\mathrm{ml}$ receptors in rat brain. Mol. Pharmacol., 39, 643-649.

WOMBLE, M.D. \& MOISES, H.C. (1992). Muscarinic inhibition of $M$-current and a potassium leak conductance in neurones of the rat basolateral amygdala. J. Physiol., 457, 93-114.

(Received January 27, 1994 Revised March 21, 1994 Accepted March 25, 1994) 